\title{
Majorities and Minorities in Former Yugoslav Countries at Turn of the $21^{\text {st }}$ Century
}

\author{
Branislav S. Djurdjev ${ }^{A}{ }^{*}$, Milka Bubalo-Zivkovic ${ }^{A}$, Andjelija Ivkov-Dzigurski ${ }^{A}$, Ljubica Ivanovic ${ }^{A}$ \\ Received: July 2009 | Revised: August 2009 | Accepted: October 2009
}

\begin{abstract}
Comparing censuses from the last decade of $20^{\text {th }}$ century with censuses taken at the beginning of $21^{\text {st }}$ century, this paper attempts to depict ethnic changes in six sovereign countries that emerged from former Yugoslavia. Such a comparison reveals ethnic clustering e.g. increased proportion of majorities who reside in their home countries, relative to their proportion in other countries of former Yugoslavia. That consequently led to ethnic homogenization, which is demonstrated by increased proportion of majorities in their native countries, relative to all minorities. Dismantling of Yugoslavia created six new minorities, because all majority nationals became new minorities in all other former Yugoslav countries except native ones. The proportion of old minorities decreases due to emigration.
\end{abstract}

Keywords: population, transitions, majorities, minorities

\section{Introduction}

This text could also have the following titles: Are we at the end of the process of balkanization? Is there end to balkanization? The end of Austro-Hungarian ancestor.

These areas are the witnesses of the breakdowns of great empires. Roman Empire broke down, followed by Ottoman Empire and Austro-Hungary. That is probably why after World War I a new transitive verb balkanize appeared in English language. Its meaning is "to divide (a territory or a group) into small, often quarrelsome parts". The example of Yugoslavia only proved the appropriateness of this concept. After collapse of Austro-Hungarian Empire, various South Slavic territories made up a state which last remnants ended on 2006. Dismantling of Yugoslavia was followed by considerable demographic changes which can be depicted using census data in the last decade of $2 \mathrm{O}^{\text {th }}$ century and at the dawn of $21^{\text {st }}$ century.

The comparison of censuses from the last decade of $20^{\text {th }}$ century $^{2}$ (table 1) with estimates and censuses taken at the beginning of $21^{\text {st }}$ century in newly-formed countries that

Without Kosovo due to lack of census data since 1981 onward

2 Actually, that was the last common census in former Yugoslavia since 31. March 1991. It was only in Macedonia that, due to certain doubts in the regularity of data, this census was annulled and the new one was conducted in 1994 emerged from former Yugoslavia shows that the total number of population in the period between censuses fell by 1716226 or $8.0 \%$ compared to 1990 . A smaller number of inhabitants were recorded in countries which were rather significantly involved in armed conflicts (Bosnia and Herzegovina, Croatia, and Serbia). The fall in the population number was probably the greatest in Bosnia and Herzegovina since that is the region where all three majorities took part in the war conflicts and where war conflicts were most severe. Unfortunately, there are no exact data since Bosnia and Herzegovina is the only country in Europe that did not conduct a census around the year of 2000. A special resolution of the United Nations induces member countries to conduct censuses around the year of 2000 at the same time following some basic recommendations (United Nations, 1997; United Nations, 2001). Starting from these documents it is strange why world organization is reserved towards the census in this country. We estimate ${ }^{3}$ that the number of population in Bosnia and

\footnotetext{
3 Using data of vital and educational statistics, as well as life expectancy we estimated the population of Bosnia and Herzegovina in the age between 0-21. By using the concept of stable population and estimating corrective factor based upon the number of deceased up to a certain age, a level of 24 models 'West" (Coale, Demeny 1983) was chosen and at the same time by applying the process of interpolation the proportion of male and female population up to 20 years of age in the total population number was estimated. That was used as a base for estimating the total number of male and female population. Age structure
}

A University of Novi Sad, Faculty of Sciences, Department of Geography, Tourism and Hotel Management, Trg Dositeja Obradovića 3, 
Herzegovina fell by almost 20 per cent compared to a total number from 1991 census (Djurdjev, 2005; Marijanac, Djurdjev, Marinković, 2001).

\section{Majority homogenization}

Table 1 shows national changes that occurred between beginning of the last decade of 20 century and beginning of the first decade of 21 century in former Yugoslavia and its former republics. Each entity has three rows: first one is absolute number, second one represents share of certain nationality in designated republic (percentages should be compared vertically), and third row represents share of certain nationality in total number of that nationality (percentages should be compared horizontally).

Absolute numbers of all nationalities, all majorities and sum of minorities, decreased at the turn of the century in former Yugoslavia. Total loss was 1716226 persons or 8.0\% of them. Despite of absolute decrease the share of Slovenians, Croats, Macedonians, and Serbs increased in the area of former Yugoslavia. It is apparent that Slovenians traditionally live only in Slovenia, and that less than $1 \%$ live in border areas of Croatia. Although Macedonians are famous migrant workers, only $2.7 \%$ of them went to work in other countries of former Yugoslavia. Macedonians are to be found in a rather significant number only in Serbia. That is the result of the colonization process after World War II. This colonization helped government to populate empty plowed fields in northern Serbia and settle houses of German expellees. That is how instead of almost 300000 Germans there were almost 250000 Yugoslavs, among them 1592 from Slovenia and 9975 from Macedonia (Djurdjev, 1994; Djurdjev, Kicoshev, Vuksanovic, 2003).

While Slovenians and Macedonians mostly live in their native republics, Croats, Muslims or Bosnians, Serbs and Montenegrins also live in a large number in other countries of former Yugoslavia. Although almost a quarter of all Montenegrins live in other republics of former Yugoslavia, their proportion in neither one of them is not even $1 \%$, whereas in their native country they represent less that a half of a total population number. The proportion of Serbs in all newly-formed countries is larger that $1 \%$, whereas in Bosnia and Herzegovina and Montenegro they represent a third of a total number of population. According to the census from 2002 the population of Serbia grew by $5.1 \%$ or 379135 people due to an influx of refugees. Yet there are still 1574948 Serbs outside Serbia on the area of former Yugoslavia at the beginning of $21^{\text {st }}$ century. These Serbs and their descendants could be an important resource in undisturbed socio-demographic development of Serbia, if ever needed by Serbia.

Interestingly, in each one of former republics and today's sovereign countries, except in Croatia, the absolute number of majority population decreased. However, a relative proportion of majorities increased apart from Croatia, also in

of the remaining population was calculated on the account of the estimated crude age and by using the same model of interpolation.
Bosnia and Herzegovina and in Serbia. In 1991 the most homogeneous republic was Slovenia with $11.7 \%$ of population that declared themselves as non-Slovenians, whereas at the beginning of $21^{\text {st }}$ century that was the case with Croatia with only $10.4 \%$ of its population that have not declared themselves as Croats. 2001 census also shows that absolute and relative numbers of all nationalities, apart from Croats, decreased in that country. Nationally most heterogeneous republic in 1991 was Bosnia and Herzegovina, in which neither one of three constituent nationalities, former Muslims (today's Bosnians or Bosniaks), Serbs or Croats, did not have absolute majority. Census from 2003 reveals that at the beginning of the first decade of $21^{\text {st }}$ century the most heterogeneous population lives in Montenegro because $56.8 \%$ of its population are not Montenegrins.

\section{Old and new minorities ${ }^{4}$}

According to the first censuses from the beginning of $21^{\text {st }}$ century, on the territory of former Yugoslavia (excluding Kosovo) there were 19742189 people, out of which constituent nationalities or majorities in former Yugoslavia counted 17482798 persons or $88.6 \%$ of total, while 2259391 people or $11.4 \%$ were represented by members of "old" minorities. That means that both the number and proportion of "old" minorities fell compared to the previous census. The greatest exodus of 'other' happened in Bosnia and Herzegovina where their number fell 2.5 times and in Croatia where it fell 1.8 times. The growth of the number and proportion happened in Macedonia and especially in Slovenia where the proportion of "others" grew almost 2.5 times. "Old" minorities are mostly to be found in Macedonia where they (Albanians with $76.7 \%$, Turks with $11.7 \%$ and Romanies with $8.1 \%$ of proportion among "old" minorities) represent a third of the whole population, whereas a bit over ten percent of them are to be found in Serbia, Montenegro, and since the last census, in Slovenia (we emphasize again that Albanians from Kosovo are not included here).

However, balkanization of former Yugoslavia also formed some "new" minorities. Outside their native republics there are additional 2604198 people or $14.9 \%$ representatives of former majorities, although we must bear in mind that about 450000 Croats and about 1.100.00o Serbs are not minorities in Bosnia and Herzegovina. When these two nationalities are excluded from this calculation, we are left with 1054198 representatives of "new" minorities. This contributed to the fact that the proportion of minorities in the area of former Yugoslavia went up by $40.5 \%$ and reached the number of 3313589 people or $16.8 \%$ of all inhabitants that at the beginning of $21^{\text {st }}$ century lived in the territory of former Yugoslavia. With Albanians from Kosovo minorities would count for more than a quarter of the population of former Yugoslavia, and that would certainly expand national tensions and ask for significant changes when defining majorities and minorities and their rights.

In this article a definition of minorities is based on quantitative/logical understanding, although minority as constitutional category may be different. 


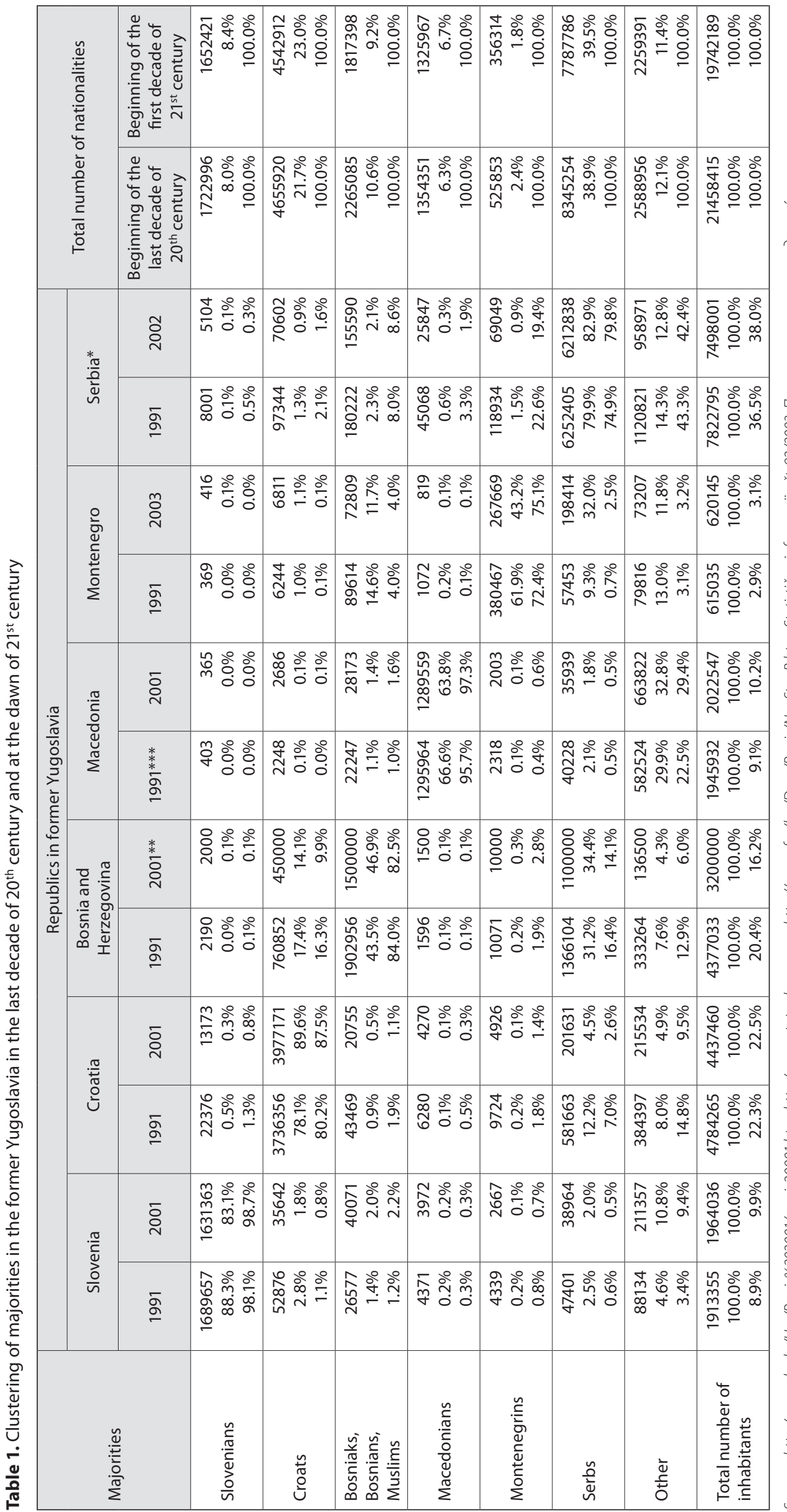




\section{Causes}

Ethnic structure of former Yugoslavia changed in the period of World War II mainly due to the differences in population growth of certain nationalities. While Slovenians, Croats, Macedonians, Montenegrins and Serbs followed European trend of demographic transition when their fertility was already from 1960 s below the level of simple replacement, Muslims, Romanies and especially Albanians had fertility double larger that one necessary for simple generation replacement. That is why the proportion of these three nationalities (especially Albanians) always grew in the total number of population in former Yugoslavia (Djurdjev, 2000). The growth of the number of Romanies was additionally influenced by the growth of ethnic conscious.

However, in the last period between censuses the causes were different. Ethnic structure was changed by voluntary or forced emigration of the members of non-constituent nationalities in a certain state, voluntary or forced immigration into native countries as well as by changes in the ideas of national affiliation. In the text that follows we will state some major cases.

\section{Migration inside former Yugos/avia}

The "exchange" of 233125 refugees from Croatia to Serbia and 19172 refugees form Serbia to Croatia resulted in positive/negative net migration that included 213953 people. This "gain" increased the number of inhabitants in Serbia in 2002 census by $2.9 \%$, i.e. this "loss" decreased the number of inhabitants in Croatia in 2001 census by $51 \%$.

In ethnical sense, both in Serbia and Croatia the proportion of majority population significantly grew (table 2). However, the ways in which ethnic homogenization was accomplished are different. In Serbia without Kosovo and Metohija the growth of the proportion of Serbs from $79.9 \%$ in 1991 to $82.9 \%$ in 2002 was accomplished due to the immigration of 218383 Serbs from Croatia, who represented $93.7 \%$ of all of those who emigrated from Croatia and who represented $3.5 \%$ of total Serbian population in 2002. In Croatia, Croats who emigrated from Serbia represent only $0,4 \%$ of the total number of Croats according to 2001 census, which means that the growth of the proportion of Croats in Croatia is the result of lessened number and proportion of non-Croats, total of 230426 of them. If there had not been refugees between Croatia and Serbia, the proportion of Croats in Croatia would have gone up from $78.1 \%$ in 1991 to only $85.2 \%$, and not even $89.6 \%$ as it was determined by 2001 census. In that case, the proportion of Serbs would have doubled; instead of 4.55 it would have been 9.05, which is still less that $12.2 \%$ which was their proportion in 1991. If the population natural growth among nations is the same then only the immigration of compatriots or the emigration of the others can contribute to the increase of the proportion of a certain nation. In this case, migration balance (i.e. moving in) of Croats on Serbia-Croatia relation contributed with only $5.8 \%$, whereas the balance of other nations (i.e. moving away) contributed to the growth in the proportion of Croats in Croatia with 94.2\% (Djurdjev, Bubalo-Zivkovic, Ivkov, 2005).

As it can be seen, a massive division of population happened between Serbia and Croatia. It must be mentioned that movement towards Serbia and Montenegro was more intense, while the movement in the other direction, towards Croatia from Serbia and Montenegro was of rather weaker intensity and even in some years rather considered as irrelevant, according to the data of UNHCR. Obviously, the most intense movement happened after war operation "Oluja" in 1995. Certain number of refugees returned to Croatia after those years. However, these returnees have not contributed significantly to the population structure in Croatia, i.e. a significant growth of the proportion of the Serbian population in the total population in Croatia has not happened.

Apart from Croatia, immigration of the large intensity happened from Bosnia and Herzegovina since 1992 when war conflict in that republic started. A large number of Croats also moved from Bosnia and Herzegovina to their native country; however, that immigration became less intense after 1996. The movement of refugees to Serbia and Montenegro was as well recorded from Slovenia and Macedonia; that movement was of rather smaller intensity than the one from Croatia and Bosnia and Herzegovina. These movements contributed to the creation of ethnically clearer areas in all republics and not just in Croatia.

Table 2. Ethnic structure of refugees from Serbia and Croatia

\begin{tabular}{|l|r|r|r|r|}
\hline \multirow{2}{*}{ Nationality } & \multicolumn{2}{|c|}{ Refugees from Serbia } & \multicolumn{2}{c|}{ Refugees from Croatia } \\
\cline { 2 - 5 } & Number* & \multicolumn{1}{c|}{$\%$} & Number** & \multicolumn{1}{c|}{$\%$} \\
\hline Serbs & 844 & 4.4 & 218383 & 93.7 \\
\hline Croats & 16770 & 87.5 & $2699^{* *}$ & 1.2 \\
\hline Other & 1558 & 8.1 & 12043 & 5.2 \\
\hline Altogether & 19172 & 100.0 & 233125 & 100.0 \\
\hline
\end{tabular}

Sources: http:/www.dzs.hr/Hrv/Popis\%202001/popis2001.htm; Refugee Corp in Serbia, 2004 (in Serbian)

*Estimated number of newborns after 1991 was added to the number of each nationals that was out of Croatia in 1991 census

**Estimate under assumption that the share of Croat refugees from Croatia is the same as the total share of Croat refugees in the total number of non Serb refugees

These consequences of divisions and/or wars are not the only case in the world. Turkey and Greece ended on January 30, 1923 the first phase of peace conference in Lausanne by signing convention that deals with the exchange of Greeks and Turks in Greece and Turkey. On the account of that convention, almost 700000 people were moved form their homes and made refugees, whereas this agreement confirmed the refugee status for more than a million people during Balkan wars in 1912-1913 (Yildirim, 2006).

Let us remember the division of Indian subcontinent in 1947 when about 6.5 million Muslims moved from India to Pakistan and about 5,5 million Hindus moved from Pakistan to India, although there are still today about a hundred million Muslims living in India whereas about ten million Hindus stayed in today's Bangladesh. Millions of Russians stayed outside Russia after the breakdown of Soviet Union in 1991.

\section{Migrations outside former Yugoslavia}

Between 1991 and 20041.3 million inhabitants of former Yugoslavia sought asylum in the western countries. Many of them got permission to stay as refugees or as beneficiaries 


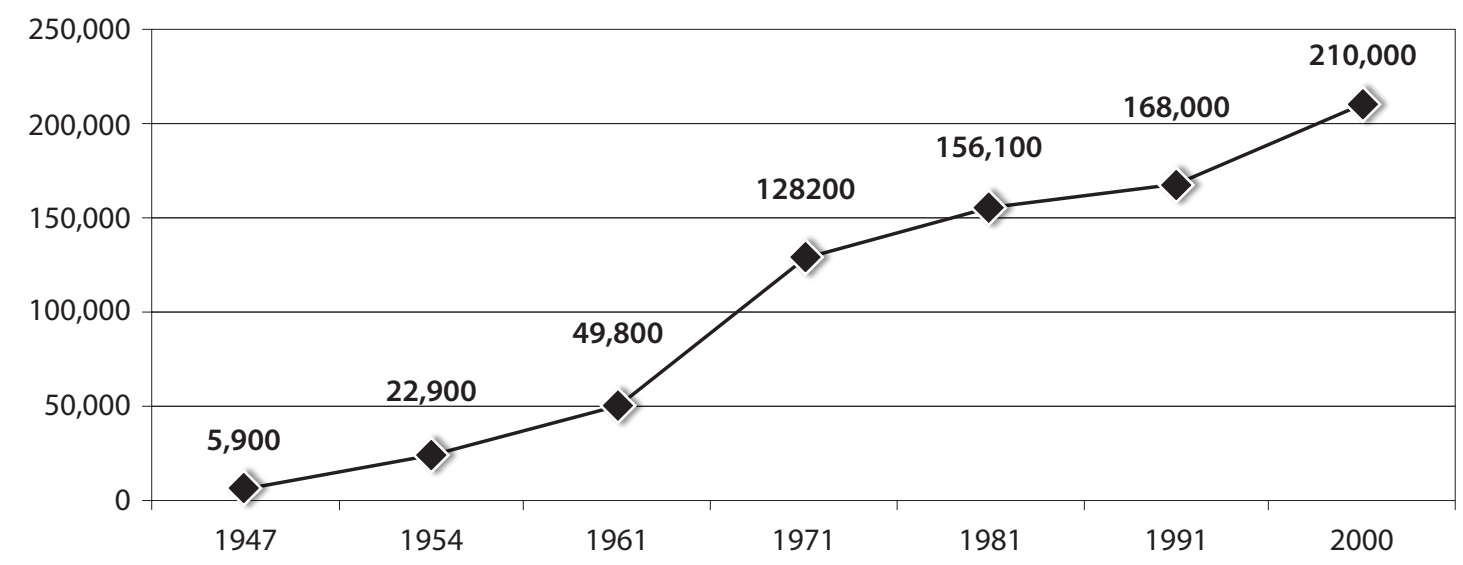

Figure 1. Number of Australian citizens born in former Yugoslavia in the period 1947-2000 Source: www.abs.gov.au/Ausstats

of humanitarian aid. More than a million of asylum seekers or $80.4 \%$ of them are from Serbia and Montenegro (including people with former Yugoslav passport), $15.6 \%$ of these people are from Bosnia and Herzegovina, $2.6 \%$ from Macedonia and $1.5 \%$ from Croatia. The majority of these people found asylum in Germany, 578322 or $44.1 \%$, whereas more than a hundred thousand of them are registered in Sweden, 172777 or $13.2 \%$ and Switzerland 148.118 or $1,3 \%$ (UNHCR, 2005).

Between 1993 and 2004 about 275000 refugees settled in Australia, Canada and USA. Almost three quarters of these settlers comes from Bosnia and Herzegovina, 205 comes from Serbia and Montenegro whereas $7 \%$ comes from Croatia (Hovy, 2005).

However, since the data obtained for former Yugoslavia until 1996 were not precisely and carefully analyzed according to national communities, it is difficult to determine correct and precise trends of migration for that period.

On the territory of Australia and according to the place of birth, in 1947 there were 5900 people born in the region of former Yugoslavia while that number in 2000 was 21000o. What is noticed is a sudden growth in the period 1991-2000 when the growth was 42000 persons or 4200 annually (figure1).

In the period $1999 / 200022 \%$ of immigrants came through Australian Immigrant Program; 3300 of them came from Europe. Almost all of them are from the area of Southern and Eastern Europe (especially from Bosnia and Herzegovina and Croatia) (www.abs.gov.au/Ausstats).

When former Yugoslavia is concerned, it is interesting that according to the proportion in the total population number in Australia and according to the place of birth of their parents, Croats are on the $17^{\text {th }}$, Serbs on the 18 th, Macedonians on the 19th, Bosnians on the $46^{\text {th }}$ and Slovenians on the 59 th place.

According to the census from 2001, the majority of people who declared themselves as members of one nation of former Yugoslavia was born in former Yugoslavia (60\% of Montenegrins, $75 \%$ of Bosnians etc.).

The number of immigrants from the Balkans on the territory of Canada in the period 1981-2001 reaches between 118000 and 220000 people. The greatest number of immigrants is concentrated in Canadian province Ontario (about $65.3 \%$ of their total number). More than $55 \%$ of them settled in the area of Toronto city. The fact that should be specially worrying for Balkan countries is the fact that $39.2 \%$ of immigrants is between 25 and 44 years of age and that $30.2 \%$ of them have university education. If only countries from the area of former Yugoslavia are concerned, what is noticeable is a great proportion of highly educated immigrants from Serbia and Montenegro (32\%), Croatia (22.8\%), Bosnia and Herzegovina (22\%), Slovenia (20.1\%) and Macedonia (16.8\%).

According to the estimates of Statistical Centre of Canada, in the period 1994-200o almost half of all immigrants came from the Balkans (46\%). This term the Balkans refers to the region that includes countries of former Yugoslavia (Serbia, Montenegro, Macedonia, Croatia, Bosnia and Herzegovina, Slovenia) and neighboring countries: Albania, Bulgaria, Romania and Greece.

Refugees from the Balkans represent a significant percentage (between 21-28\%) of the total number of refugees recorded in Canada during the second half of 1990s (www. statcan.ca).

The number of immigrants grew from year to year. Thus, 2900 people were recorded in 1987, 1991 (5200), 1992 (8200), period between 1993-95 (15900), 1998 (11000), period between 1999-2000 (14700), and 2004 (10000).

In the period 1994-2000, the greatest number of refugees from certain countries of former Yugoslavia immigrated to Canada (62\% from Serbia and Montenegro, 61\% from Croatia and even 91\% from Bosnia and Herzegovina).

According to the census from 2001, the number of those that were born on the area of former Yugoslavia reached from 91600 (1981) even 145400 (2001) (figure 2).

If specific countries of former Yugoslavia are observed, it is noticeable that the greatest number of immigrants in Canada up to 1980 s was born in Croatia (27100) and Serbia and Montenegro (26800), only that in period 1981-1991 the number of immigrants from Serbia and Montenegro was 4300, followed by those from Croatia 2600, whereas other former Yugoslav republics were present in minor numbers. However, there is a sudden growth in the number of immigrants in the period 1991-2001, when the number of those born in Serbia and Montenegro reaches 32800 and those born in Bosnia and Herzegovina (22600), followed by Croatia (9600), while Macedonia (2200), and especially Slovenia (500) are represented in significantly smaller numbers. 


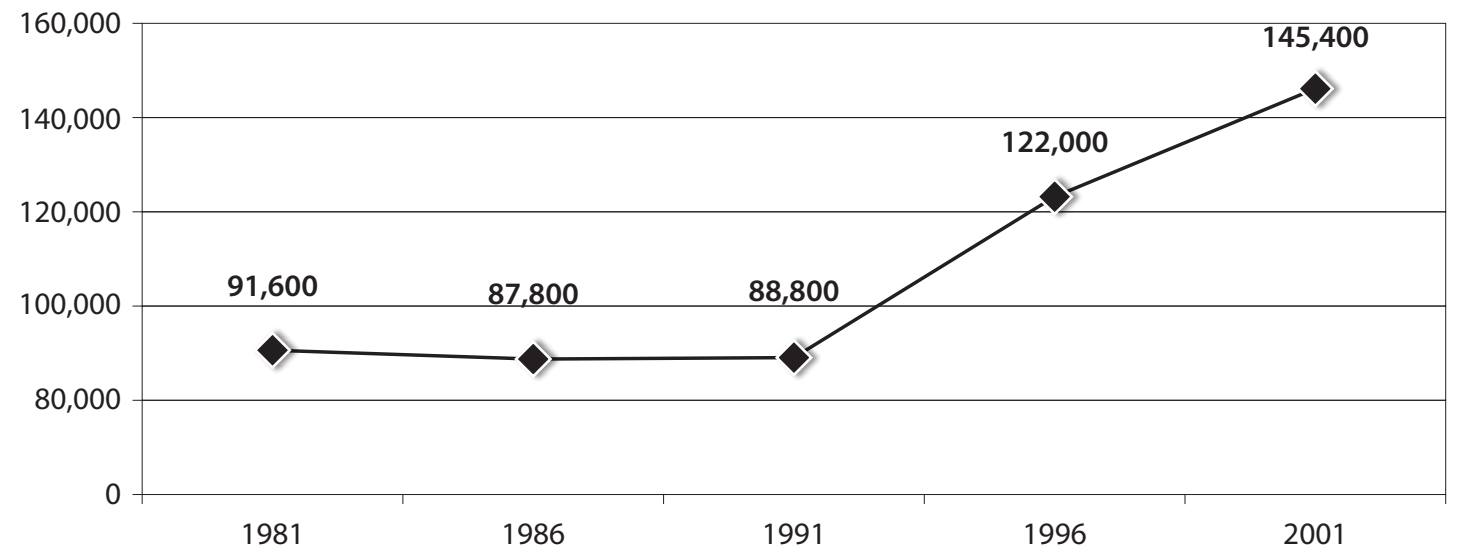

Figure 2. Number of Canadian citizens born in former Yugoslavia in the period 1981-2001

Source: Malenfant Eric Caron, Laurent Martel, 2003-2004. Recent immigration to Canada from the Balkans. Report on the DemographicSituation in Canada. Catalogueno. 91-209-XIE

If the total for period up to 2001 is observed (graph 3), on the territory of Canada there were 63900 immigrants born in Serbia and Montenegro, 39400 born in Croatia, 25700 in Bosnia and Herzegovina, 9300 in Slovenia and only 7200 of them born in Macedonia (Malenfant, Martel, 2003-2004).

Apart from migrations to Canada and Australia rather significant are migrations from the areas of former Yugoslav republics towards European countries, as well as towards the USA.

From Bosnia and Herzegovina, as it was already mentioned, there was a great migration into Serbia and Montenegro, where in 1992, there were already 350000 refugees. A great number of them also reemigrated to Germany. However, this country experienced a more massive migration somewhat later, in 1994. Apart from Germany, Scandinavian countries such as Sweden and Denmark became rather interesting to refugees from this republic, as well as the Netherlands at the end of the $20^{\text {th }}$ century. However, apart from Germany the greatest number of them left for the USA. In 2001 more than 108000 refugees from Bosnia and Herzegovina were recorded in this country.

Croatia experienced the most massive migration towards Serbia and Montenegro especially in the second half of the last decade of the $2 \mathrm{O}^{\text {th }}$ century. Migration towards other countries compared to this one toward Serbia can be neglected. Due to economic reasons, the population moved to the USA and Germany at the beginning of 21st century.

Macedonia did not experience such a massive emigration during 1990 oxcept towards Italy. The number of emigrants grew at the end of 1990 s and at the beginning of the $21^{\text {st }}$ century. That was when the conflicts on Kosovo intensified so that population moved away from those municipalities near the border with Kosovo, i.e. from those municipalities where Albanian or Muslim population was rather dominant. The emigration towards Germany intensified at the beginning of 2000 and later. There were no direct ethnic war operations in Serbia and Montenegro; however, economic consequences of war in neighboring countries as well as the bombing of 1999 led to emigration of population from Serbia. This emigration did not lead to the changes in ethnic structure on the area of Serbia and Montenegro. The greater influence upon ethnic structure was due to immigration from other republics. The number of Serbian population significantly grew, especially on the territory of Vojvodina. The greatest number of emigrations from Serbia and Montenegro happened during 1990s towards Sweden and Australia, and at the beginning of $21^{\text {st }}$ century towards Germany. Emigrations of population from Serbia did not

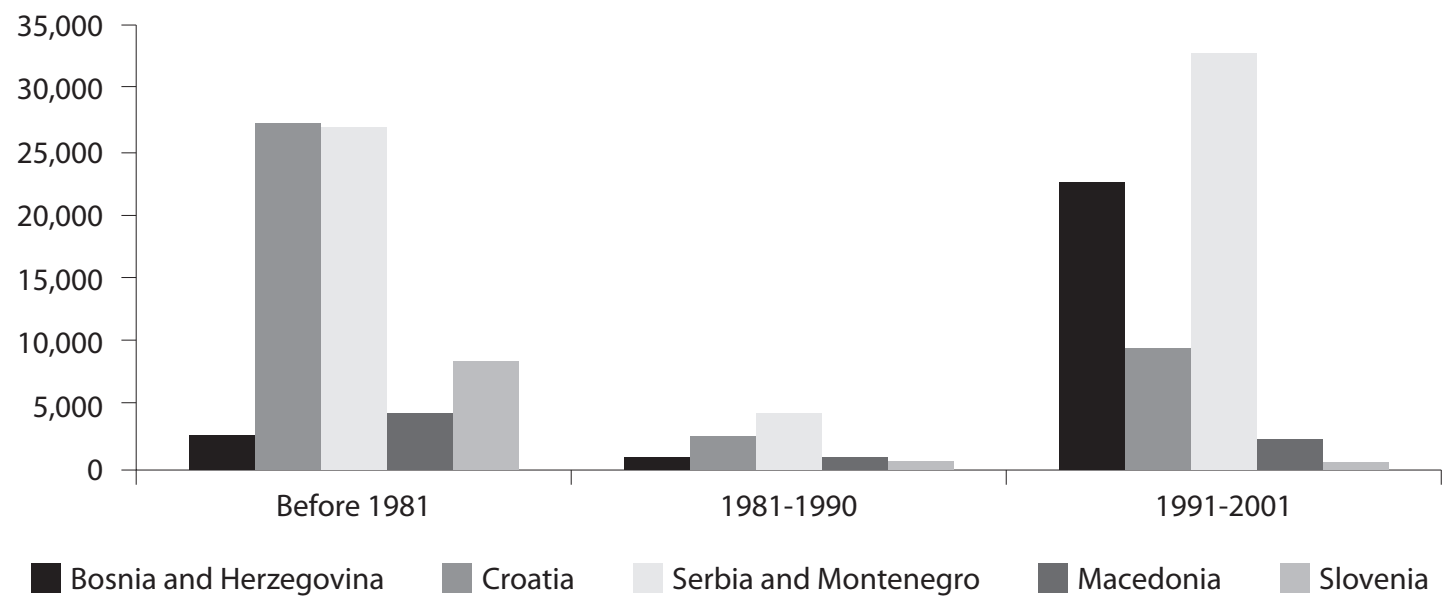

Figure 3. Number of immigrants in Canada born in of republics of former Yugoslavia 


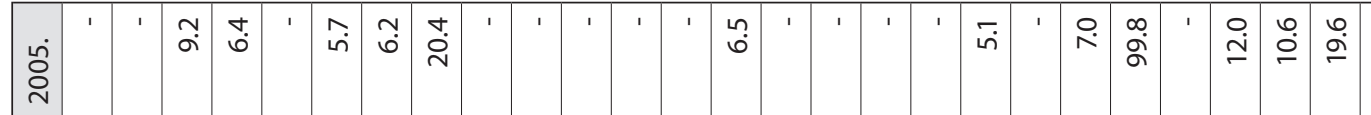

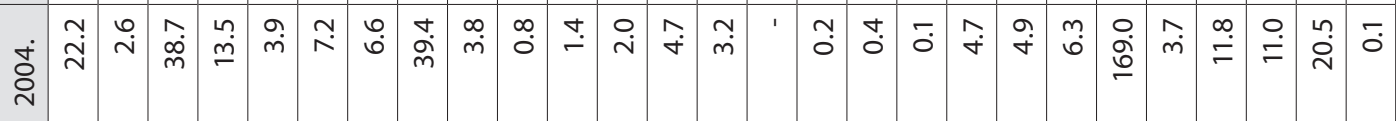

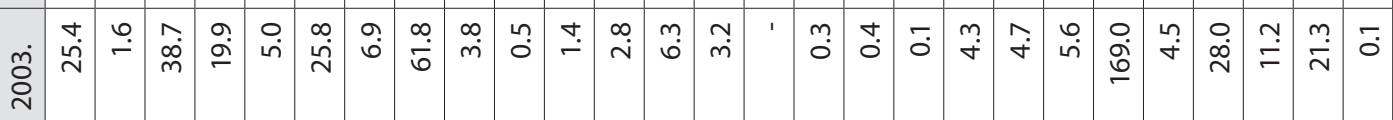

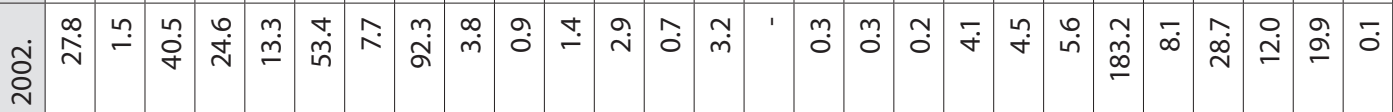

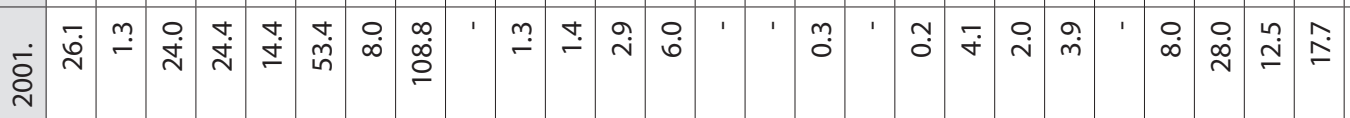

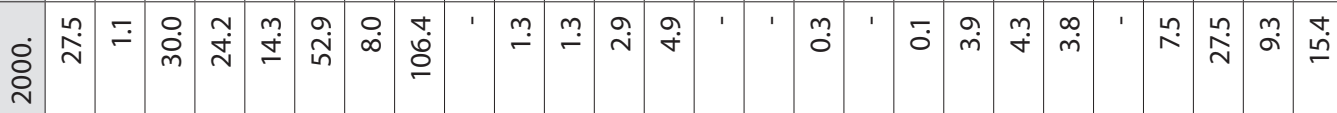

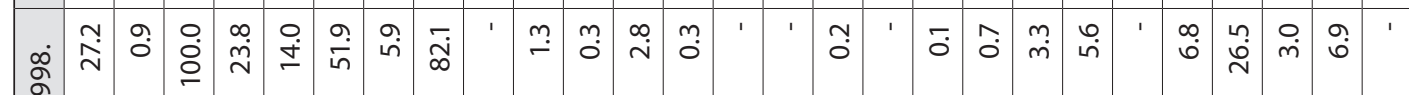

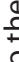

.

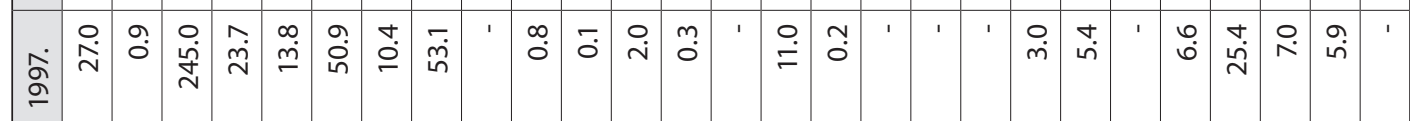

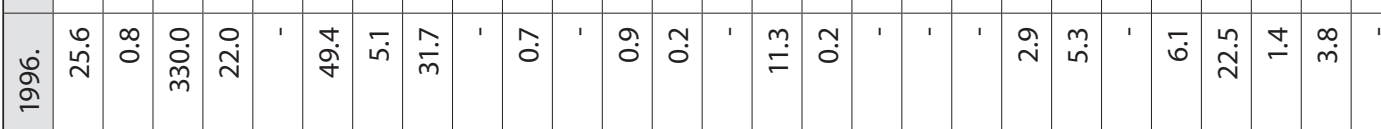

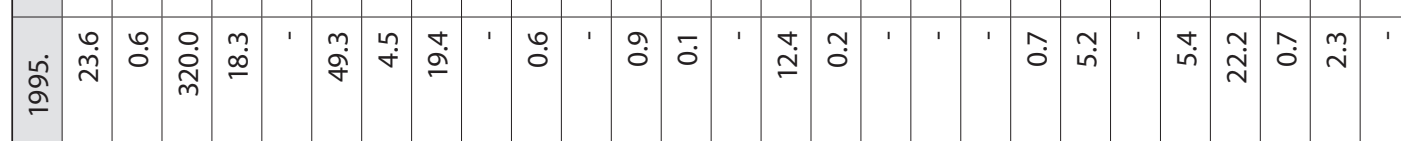

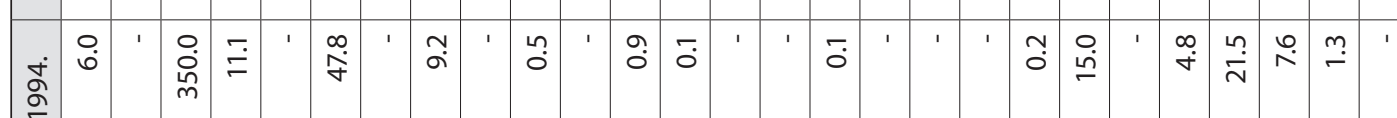

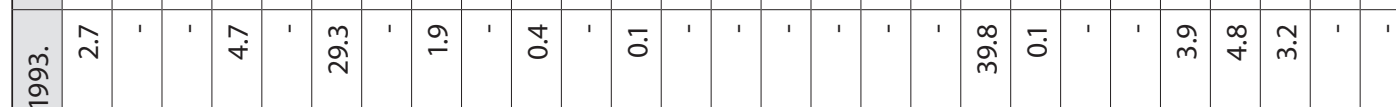
ふั่ ơ $\stackrel{y}{\grave{y}} \overline{0}$ ' $\quad \overline{0} \bar{m}$

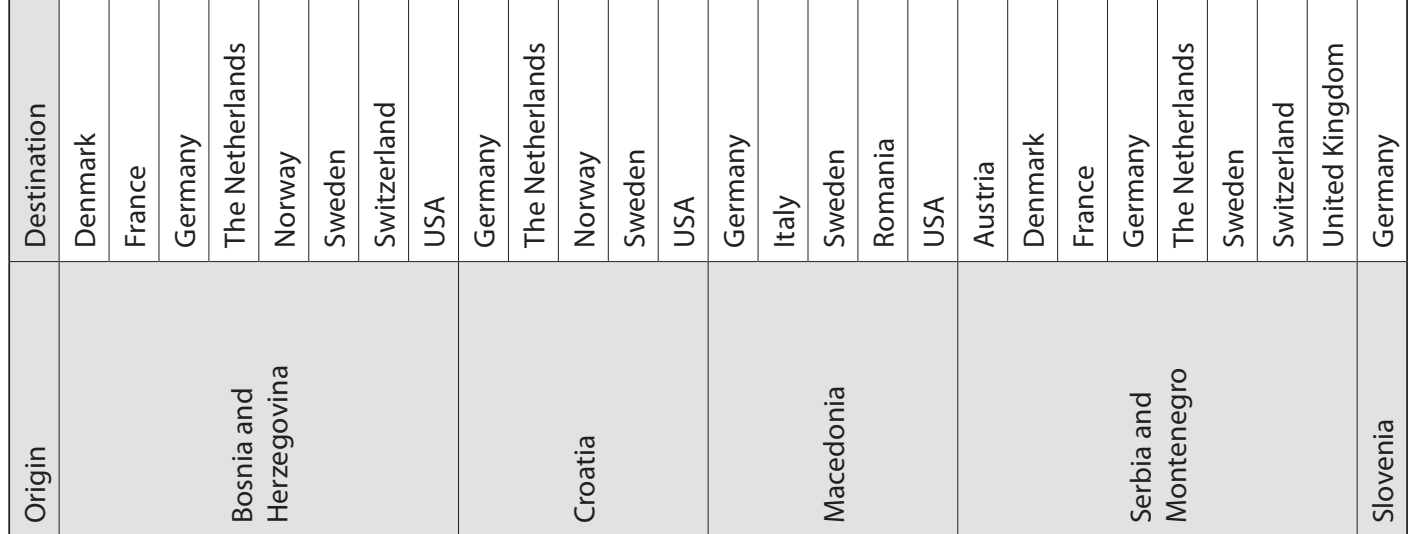


weaken at the beginning of $21^{\text {st }}$ century which represented a great problem for this country since younger, educated population is the one that usually moved away.

Ethnic conflicts in former Yugoslavia began in Slovenia at the beginning of 1990 s which meant that emigration from this republic was most intense at the beginning of 1990 os mostly towards Serbia, as it was already mentioned. Apart from migrations to Serbia, Slovenian population also moved to Germany but in much smaller extent. The main reason of the fast reduction in the number of emigrations among Slovenians was economic stabilization in this county as well as the standard of living (table 3).

\section{The case of Montenegro}

If we observe the numbers and proportion of Montenegrins and Serbs in Montenegro collectively we notice only small changes in the period between censuses. However, it is noticeable that the number of Montenegrins in 2003 census fell by almost a third compared to the census from 1991, whereas the number of Serbs grew 2.5 times (Penev, 2003; Raduški, 2005). Although the census was conducted in the time of very intensive discussions about legal status of this country, this phenomenon cannot be explained as a temporary political situation because the number of Montenegrins in Montenegro fell and the number of Serbs grew since the census from 1981. The explanation is more probably that Montenegrins in Montenegro did not have a clear concept of a difference between belonging to a state (citizenship) and belonging to a nation (nationality). Opinions and discussions on the independence initiated the beginning of the division between concepts of citizenship and nationality.

Apart from ideological influences upon the growth in the number of Serbs in the last period between censuses in Montenegro, certain influence belongs to refugees as well. At the beginning of 1990 s refugees from Slovenia and Croatia started coming to Montenegro. In 1992 there were 63050 refugees from Bosnia and Herzegovina which was about $10 \%$ of the total population in Montenegro. In 1994 and 1995 there was a fall in the number of refugees, about 45000 of them. After conflicts in Croatia, about 4000 people came from this republic to Montenegro in August 1995 and after Dayton peace agreement about 2000 refugees came from Bosnia and Herzegovina. Until 1998 the number of refugees fell to 23350 which represented about $5 \%$ of the total population in Montenegro (Remiković, 2005).

As the result of political tensions and war conflicts in the last decade of the $20^{\text {th }}$ century there were some great demographic changes on the territory of former Yugoslavia. The population number of all nationalities is significantly smaller, of both majorities and minorities, mainly due to major emigrations to foreign countries which still last today. Majorities became more concentrated in their native states, some by their free will and some by force, which means that there is less and less of them in other countries of former Yugoslavia. Those who remained in other countries became "new" minorities and thus with other "old" minorities increased the total proportion of minorities.

The worst and most dangerous demographic consequence is massive exodus abroad, especially from Serbia and Bosnia and Herzegovina. That massive emigration that happened after the bombing in Serbia and after the end of war conflicts in Bosnia and Herzegovina represents a great economic loss for both of these countries because the population that emigrates is usually highly educated; the one that highly developed countries also seek for. Already bad economic situation in Serbia and in Bosnia and Herzegovina is left without its educational force that would represent the potential and brain of its recovery. What happened is that, due to the situation, quality and young educated people went to the countries of Western Europe, America, Canada and Australia.

Eastern European countries have the same kind of problems with depopulation like western countries but have no economy that could attract foreign labor force. However, in Russia in 2002 there were over 13 million new immigrants, mostly Russians that experienced breakdown in one of the countries of the former Soviet Union. That is how Russia holds the second place when the number of immigrants is in question. Only the USA is in front of it. To attract compatriots will still be Russian priority, and they will especially "stimulate the immigration of qualified, educated and honest citizens" (PDR, 2006, 387). Because of long lasting below replacement fertility level and lack of in-migration from China, India etc. (those migrations are directed toward Western European countries due to tradition and economy) one can expect that demographic policy of all former Yugoslav countries will continue to attract their compatriots back to their roots. The degree of ethnic clustering in all former Yugoslav countries will presumable continue to increase in the future.

\section{Aknowledgements}

This work is part of the project No. 146017 financed by the Ministry of Science of the Republic of Serbia. Authors want to thank M.S.Goran Penev from the Centre of Demographic Researches for all the information he provided them with.

\section{References}

Coale, A., Paul, D., Barbara, V. 1983. Regional Model Life Tables and Stable Populations. Academic Press, San Diego.

Djurdjev S. B., Kicoshev S, Vuksanovic G., 2003. Strenghts and Weaknesses of Human Resources in Regional Development of Vojvodina Province. Geographica Pannonica 7, 21-26.

Djurdjev, S.B. 1994. Peopling of the Voivodina Province. The First Regional Geography Conference "Geographical Researches in the Carpathian-Danube Space", Universitatea de Vest din Timisoara, Timisoara, 139-148.

Djurdjev, S.B. 200o. Problems of Regional Population Growth in Serbia. GeoJournal 50, 133-138.

Djurdjev, S.B. 2005. World's Experiances with Population Cenuses. Glasnik Geografskog društva Republike Srpske 9, 115-124. (in Serbian).

Djurdjev, S.B., Bubalo-Zivkovic, M., Ivkov, A. 2005. Migratory Changes between Croatia and Serbia and their 
effects on Demographic and Ethnic Structure of Population in Regions of Emigration and Immigration. International Scientific Conference Migrations, Crises and Recent Conflicts in the Balkans, DEMOBALK ("Démographie des Balkans") network, 27-29 October 2005, Belgrade.

Hovy, B. 2005. How Many Have left? Displacement of Citizens from Former Yugoslavia. International Scientific Conference Migrations, Crises and Recent Conflicts in the Balkans, DEMOBALK ("Démographie des Balkans") network, 27-29 October 2005, Belgrade.

Marijanac Z., Djurdjev S.B., Marinković, D. 2001. SocioDemographic Structure of the Border Area in the Northwest Part of Republic of Srpska. Geographica Pannonica 5, 8-12.

Ministry of Human and Minority Rights. Refugee Corp in Serbia, Belgrade. (in Serbian).

Malenfant, E.C., Laurent, M. 2003-2004. Recent immigration to Canada from the Balkans. Report on the Demographic Situation in Canada. Catalogueno 91-209-XIE.

PDR. Documents, 2003. Vladimir Putin on Raising Russia's Birth Rate. Population and Development Review 32,2, 385-389.

Penev, G. 2003. Population Census of Montenegro. Pregled 4, 3-20. (in Serbian).

Завод за статистика, 1994. Попис на населението, домак'инствата, становите и земјоделските стопанства во Република Македонија. Книга 1, Скопје.

Raduški, N. 2005. Minorities in Montenegro. Pregled 4, 3-15. (in Serbian).

Statistical Office of Serbia Republic, 2004. Population, Household and Dwelling Census 2002, Migration characteristics. Book 8, Belgrade. (in Serbian)
Remiković, S. 2005. Demographic characteristic of refugees and displaced persons in Montenegro according to Census of population, household and dwelling 2003. In ternational Scientific Conference Migrations, Crises and Recent Conflicts in the Balkans, DEMOBALK ("Démographie des Balkans”) network, 27-29 October 2005, Belgrade.

Statistične informacije, št. 92/2003. Statistični urad Republike Slovenije.

UNHCR, 2005. Statistical Yearbook 2003. Geneva.

UNHCR, Statisticl Yearbook 2000-2005. Geneva.

United Nations, Department of Economic and Social Affairs, Statistics Division, 1997. Principles and Recommendations for Population and Housing Censuses, Revision 1, New York.

United Nations, Department of Economic and Social Affairs, Statistics Division, 2001. Handbook on Population and Housing Censuses, New York.

Vanderburie, J. 2005. Géographie des mouvments de réfugiés dans les Balkans après 1989: des origines aux destination. International Scientific Conference Migrations, Crises and Recent Conflicts in the Balkans, DEMOBALK ("Démographie des Balkans") network, 27-29 October 2005, Belgrade.

Yildirim, O. 2006. The 1923 Population Exchange, Refugees and National Historiographies in Greece and Turkey. East European Quarterly XL,1, 45-71.

http:/www.abs.gov.au/Ausstats

http:/www.montenegro.org.au

http:/www.statcan.ca

http:/www.dzs.hr/Hrv/Popis\%202001/popis20oo1.htm

http:/www.statserb.sr.gov.yu

http://www.fzs/ba/Dem/Popis/NacStanB.htm 